International Journal of Engineering \& Technology, 5(3) (2016) 70-76
International Journal of Engineering \& Technology
SPC
Website: www.sciencepubco.com/index.php/IJET
doi: $10.14419 /$ ijet. $v 5 i 3.6195$
Research paper

\title{
Bending Strength of Welded Joints in TMCP Steel Square Tubular Profiles "T" Connexions
}

\author{
Rafael Luciano Dalcin ${ }^{1 *}$, Ivan Guerra Machado ${ }^{1}$, Arnaldo Ruben Gonzalez ${ }^{2}$, \\ Cintia Cristiane Petry Mazzaferro ${ }^{2}$ \\ ${ }^{1}$ Federal University of Rio Grande do Sul, PPGE3M, Welding \& Related Techniques Laboratory, Porto Alegre, RS, Brazil \\ ${ }^{2}$ Federal University of Rio Grande do Sul, PROMEC, Welding \& Related Techniques Laboratory, Porto Alegre, RS, Brazil \\ *Corresponding author E-mail: rldalcin@gmail.com
}

\begin{abstract}
The use of DOMEX $700 \mathrm{MC}^{\mathrm{TM}}$ steel weldments is still little explored, due to some concern of the validity of the rules imposed by several standards and Codes for this class of steel. This material has low ductility and consequently the relation between tensile strength and yield strength is significantly lower than ordinary structural steels. For this reason, the instability phenomena are more critical than the instability phenomena of ordinary structural steels. Therefore, the aim of this study was to obtain detailed data on the mechanical efficiency of joints welded by GMAW. Six different heat inputs were used on square tubular profiles of TMCP steel. The tubular profiles were placed as a column/beam weldment with transverse and longitudinal welds positioned in relation to the loading axis. Twelve welded structures were instrumented with extensometer and tested in simple bending. Comparing the obtained data, it was verified that longitudinal welded joints presented higher bending strength than transversal welded joints. In the case of longitudinal joints, two weld beads were subjected to bending efforts, and in the case of transverse joints, only one weld bead resisted bending forces.
\end{abstract}

Keywords: GMAW; TMCP Steel; Tubular Profile; Welded Joint Bending Strength.

\section{Introduction}

Steel industry has devoted great efforts to find ways to promote the reduction of carbon emission and, by doing so, improve the toughness and weldability of steels without compromising its mechanical strength [1]. The steel DOMEX 700 MCTM, according to SSAB TUNNPLAT [2] meets or exceeds the requirements in EN 10149-2 [3], and commercially fits in this category. These steels are produced by a thermomechanical-controlled process (TMCP) and they are generally used in applications such as cranes, earthmoving and road and agricultural equipment, bus chassis and automotive industries [2].

Currently, the knowledge about strength reduction of heat affected zone (HAZ) for welded joints using the TMCP steels is insufficient. It is possible that this reduction of the strength by HAZ would decrease the expected (by the designer) mechanical strength of the project. Therefore, to avoid failures, it is necessary for the engineer to have more precise data about the mechanical properties of the welded joint [4]. In the current "state of art", the only way to obtain these data is by testing manufactured structures using welding procedures as closer as possible to the ones used in a real structure. Nevertheless, steel manufacturers do not generally provide detailed information about the mechanical efficiency of the welded joints. Given these factors, the heat input is strictly limited to avoid any reductions in the strength by HAZ. However, in this kind of procedure two important factors are usually ignored: the thermal cycling and its effect on the mechanical efficiency of the welded joint [5].

Despite the apparent simplicity of the welded joints, finite elements modeling has shown that the way the load transfer causes an extremely complex internal strain systems between their mem- bers. The strain concentrations produced by welded joints reduce the static loading strength and decrease the fatigue strength of the connecting members, as well as the intensity of the impact loading capacity [6]. When subjected to loading, the welded joints usually fracture in the regions of lower hardness of HAZ, as long as HAZ strength is lower than the base metal. In order to avoid the mechanical properties to be compromised in these kind of welded joint steels, some manufacturers recommend heat inputs relatively low, i.e., lower than $1 \mathrm{~kJ} / \mathrm{mm}$ [2].

This study aims to determine the effects of heat input on possible strength reduction in the heat affected zone (HAZ), and to evaluate the influence of weld bead position on the bending strength of welded joints by gas metal arc welding (GMAW) process on " $\mathrm{T}$ "

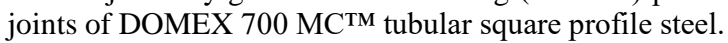

\section{Material and methods}

\subsection{Base metal}

DOMEX $700 \mathrm{MC}^{\mathrm{TM}}$ square tubular profile steels with seam (longitudinally welded), with dimensions of $100 \times 100 \mathrm{~mm}$ and $3 \mathrm{~mm}$ wall thickness were used as base metal (BM). Four samples were used to evaluate the mechanical properties of BM. The samples were extracted in the rolling direction and tensile tests were performed according to Brazilian Association of Technical Standards (NBR) 6892 [7]. Table 1 shows the base metal chemical composition. 
Table 1: Chemical Composition of the DOMEX 700 MCTM Steel [5]

\begin{tabular}{llllll}
\hline \multicolumn{7}{c}{ Base Metal Chemical Composition (mass \%) } \\
\multicolumn{1}{c}{$\mathrm{C}$} & \multicolumn{1}{c}{$\mathrm{Si}$} & \multicolumn{1}{c}{$\mathrm{Mn}$} & \multicolumn{1}{c}{$\mathrm{P}$} & \multicolumn{1}{c}{$\mathrm{S}$} & \multicolumn{1}{c}{$\mathrm{Cr}$} \\
\hline 0.0678 & 0.0468 & \multicolumn{1}{c}{1.98} & \multicolumn{1}{c}{$<0.006$} & \multicolumn{1}{c}{$<0.0010$} & \multicolumn{1}{c}{0.041} \\
$\mathrm{Mo}$ & $\mathrm{Ni}$ & $\mathrm{Al}$ & $\mathrm{Co}$ & $\mathrm{Cu}$ & $\mathrm{Nb}$ \\
$<0.005$ & 0.0289 & 0.0292 & 0.0163 & $<0.0100$ & 0.0555 \\
$\mathrm{Ti}$ & $\mathrm{V}$ & $\mathrm{W}$ & $\mathrm{Pb}$ & $\mathrm{Sn}$ & $\mathrm{B}$ \\
0.106 & 0.0164 & $<0.010$ & $<0.0020$ & $<0.0010$ & $<0.0001$ \\
\hline
\end{tabular}

\subsection{Welding procedure}

Square hollow sections were welded in the flat position, using automatic gas metal arc welding (GMAW) process. A mix of 75\% $\mathrm{Ar}$ and $25 \% \mathrm{CO}_{2}(25 \%)$ with flow rate of $15 \mathrm{l} / \mathrm{min}$ was used as shielding gas. All the weld beads were made with working angle and travelling angle of $0^{\circ}$. Contact tip to work distance (CTWD) of $20 \mathrm{~mm}$ was used. For the automation of GMAW welding, a computerized numerical control (CNC) robot (TARTÍLOPE V4 model) was used with the multiprocess welding power supply (DIGI plus A7 450). Fig. 1 shows the devices used to ensure the positioning and fastening of the parts in the flat position.

Fig. 2 shows the schematic view and cross section dimensions the transverse and longitudinal welds. The weld return ends had 10 $\mathrm{mm}$ length. It is also intended to analyze the influence of welding on the formed region.

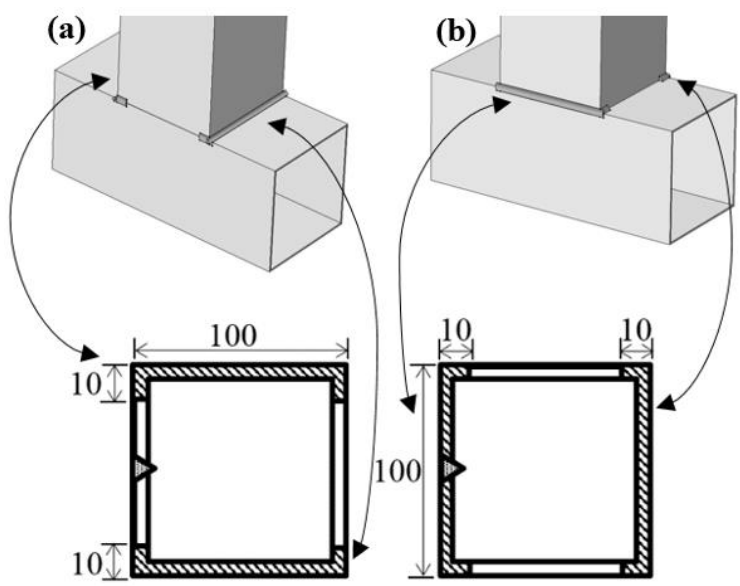

Weld bead $\square$ Seam tube $\square$ Base metal

Fig. 2: View the Cross Section of the Weld Beads: (a) Transverse Weld; (b) Longitudinal Weld.

AWS ER120S-G solid wire $(1.2 \mathrm{~mm})$ was used as filler metal, resulting in an "overmatching", i.e., weld metal has greater mechanical strength than the base metal [8-10]. Table 2 shows the mechanical properties of the filler metal used, according to manufacturer [11] and AWS D1.1 [12].

The six different heat inputs were obtained by varying welding speed, voltage and current. Table 3 shows the welding parameters used.
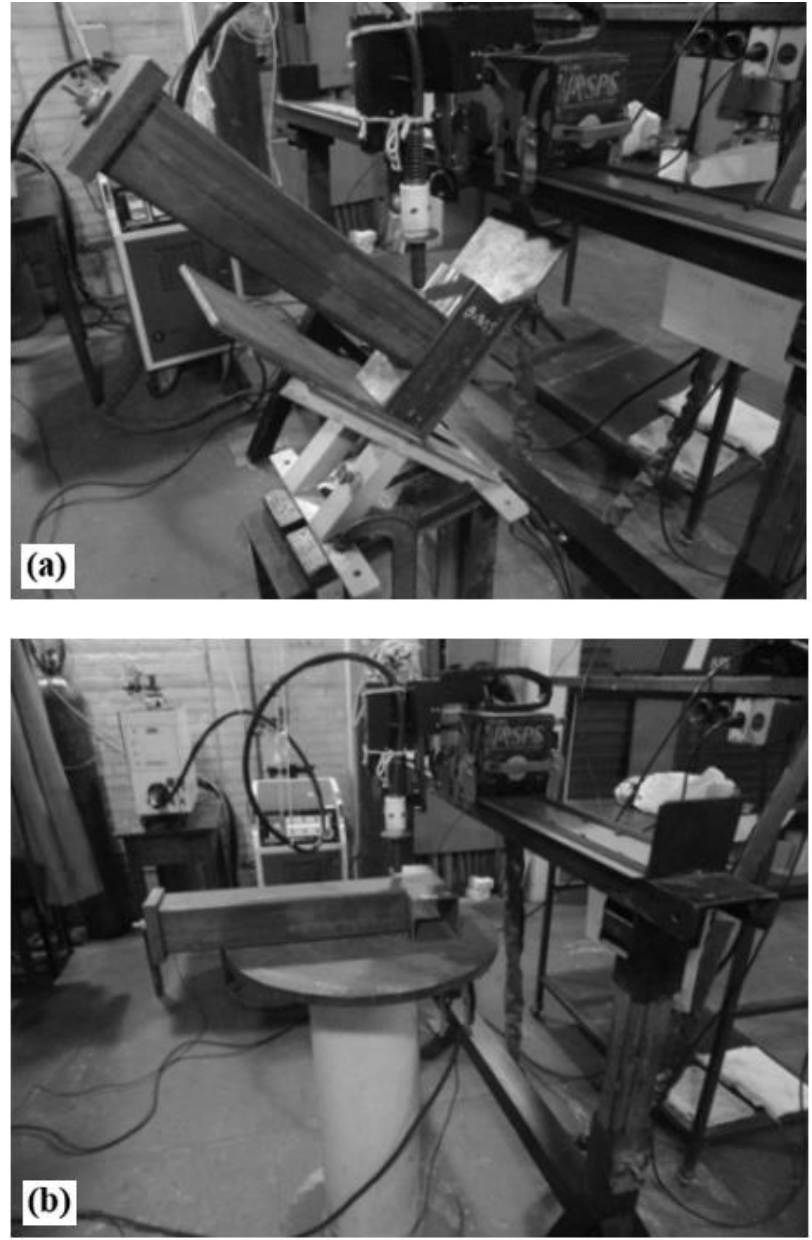

Fig. 1: Parts Assembled on the Device and Positioned for Welding: (a) Transverse Weld; (b) Longitudinal Weld.

Table 2: Filler metal mechanics properties (minimum values)

\begin{tabular}{cccccc}
\hline \multicolumn{2}{c}{ Yield Strength (MPa) } & \multicolumn{2}{c}{ Tensile Strength (MPa) } & \multicolumn{2}{c}{ Elongation (\%) } \\
\hline Manufacturer & AWS & Manufacturer & AWS & Manufacturer & AWS \\
810 & $*$ & 900 & 830 & 18 & $*$ \\
\hline
\end{tabular}

* Is not specified; It must be established between the buyer and the supplier.

Data acquisition of thermal cycles of the weld pool were made by thermocouples type $\mathrm{S}$, directly positioned on it during welding. The thermocouples were connected directly to a 32 channels acquisition system, with an acquisition frequency of $100 \mathrm{~Hz}$.

Table 3: Parameters Used for the Realization the Weld Beads [5]

\begin{tabular}{|c|c|c|c|c|c|c|}
\hline Condition & Experiment & $\begin{array}{c}\text { Average Voltage } \\
\text { (V) }\end{array}$ & $\begin{array}{l}\text { Average Current } \\
\text { (A) }\end{array}$ & $\begin{array}{l}\text { Welding Speed } \\
(\mathrm{mm} / \mathrm{s})\end{array}$ & $\begin{array}{l}\text { Average Heat Input } \\
(\mathrm{kJ} / \mathrm{mm})\end{array}$ & $\begin{array}{l}\text { Wire Feed Speed } \\
(\mathrm{m} / \mathrm{min})\end{array}$ \\
\hline \multirow{6}{*}{ Longitudinal weld* } & E1/120 & 22.5 & 139 & 9.2 & 0.3 & \multirow{3}{*}{4.0} \\
\hline & $\mathrm{E} 2 / 120$ & 22.2 & 142 & 5.0 & 0.6 & \\
\hline & E3/120 & 22.0 & 145 & 3.5 & 0.9 & \\
\hline & E4/120 & 22.1 & 136 & 2.5 & 1.2 & 3.7 \\
\hline & $\mathrm{E} 4 / 120$ & 22.1 & 129 & 2.0 & 1.4 & 3.5 \\
\hline & $\mathrm{E} 6 / 120$ & 22.4 & 113 & 1.5 & 1.6 & 3.2 \\
\hline \multirow{5}{*}{ Transverse weld* } & $\mathrm{E} 8 / 120$ & 22.2 & 148 & 5.0 & 0.6 & \multirow[t]{2}{*}{4.0} \\
\hline & E9/120 & 21.9 & 150 & 3.5 & 0.9 & \\
\hline & E10/120 & 22.1 & 139 & 2.5 & 1.2 & 3.7 \\
\hline & $\mathrm{E} 11 / 120$ & 22.1 & 134 & 2.0 & 1.4 & 3.5 \\
\hline & $\mathrm{E} 12 / 120$ & 22.4 & 112 & 1.5 & 1.6 & 3.2 \\
\hline
\end{tabular}

* Denominations in relation to load application direction. All welds were produced in the flat position. 


\subsection{Characterization of welded joints}

For each condition (type of joint and heat input), three samples of the welded joint cross section were cut to perform metallographic tests, following American Society for Testing and Materials (ASTM) E3-95 [13]. After sanding, the samples were etched with Nital $2 \%$ for approximately 15 seconds. Then, the samples were washed with water and dried. The macrophotographies of the joints were recorded with a stereo metallographic microscope, and the geometry of the welded joints (total weld metal area (WM); total HAZ grain coarsening region (GCR) area; throat) were measured with "Image J" software. The throat thickness was measured according to the procedure indicated in Fig. 3. Then, these values were used to determine the area of resistance section of the welded joints (throat $\mathrm{x}$ weld length).

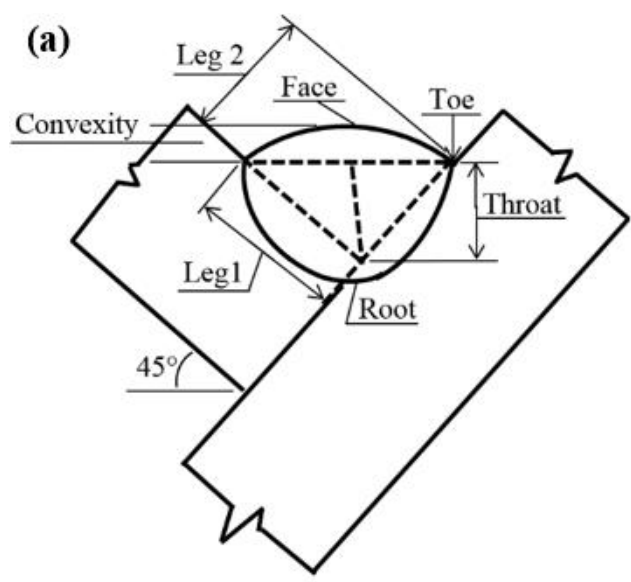

(b) Existent joint before welding

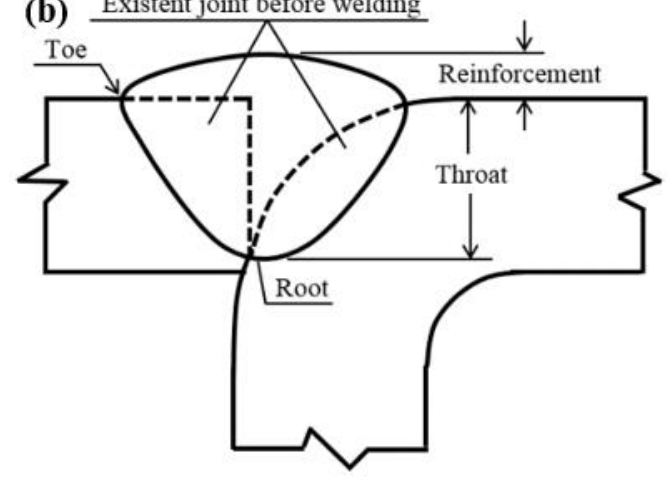

Fig. 3: Position (Flat) for Welding the Joints: (a) Transverse Joint; (b) Longitudinal Joint.

Subsequently, using the same samples, the microhardness profiles were performed on welded joints with $500 \mathrm{gf}$ load for 10 seconds, following recommendations of ASTM E384-11 [14]. Based on macrophotographies and microhardness profiles from different regions of the welded joint, it could be inferred its locations. In Fig. 4 it is schematically shown the path on which the microhardness was measured on WM, HAZ and base metal unchanged (BMU).

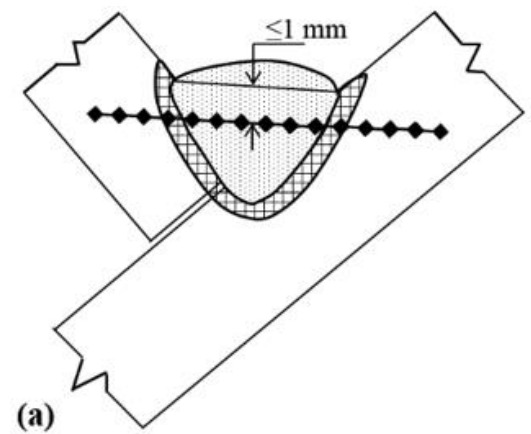

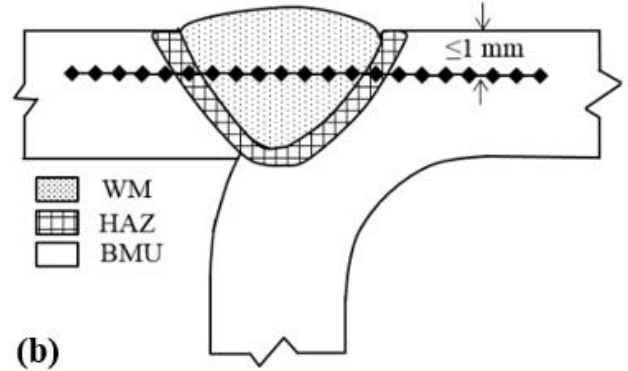

Fig. 4: Schematic Drawing the Line where the Microhardness Profiles Were Performed: (a) Transverse Joint; (b) Longitudinal Joint.

\subsection{Simple bending}

The behavior of welded joints, when subjected to bending forces, was evaluated by means of a workbench. The bench was equipped with an automated hydraulic system for the transmission of the efforts. A portico was built of a rigid steel welded profile for fastening of the structures to be tested in the bench. To assure the stiffness of the structure, a column was fixed at both ends. To guarantee the transmition of the load to the structure, a bracket was fixed and welded on the beam.

There was also as part of the workbench a data acquisition system, which receives information from the extensometer, the linear variable differential transformer (LVDT) and the load cell, and sends it to a computer. The strain data from the load cell was received by the acquisition system in a Wheatstone full bridge. The measurements of the vertical displacement of the hydraulic cylinder piston were performed with the LVDT using the Wheatstone in $1 / 2$ bridge configuration. Using the same system, the specific strain from the structure were measured by extensometers Wheatstone $1 / 4$ bridge configuration and connected with three wires. During the bending test, these strains were measured by uniaxial and triaxial (a.k.a. rosette) extensometers placed on the beam, with a distance of 30 $\mathrm{mm}$ column or $530 \mathrm{~mm}$ of the load application point.

In the bending test, the structure strain speed, i.e., the loading speed, was maintained at $0.2 \mathrm{~mm} / \mathrm{s}$ and measurements of the test terminated after the rupture the structure. Fig. 5 schematically illustrates the weldment dimensions, as well as loading point, and positioning location of extensometers and LVDT.

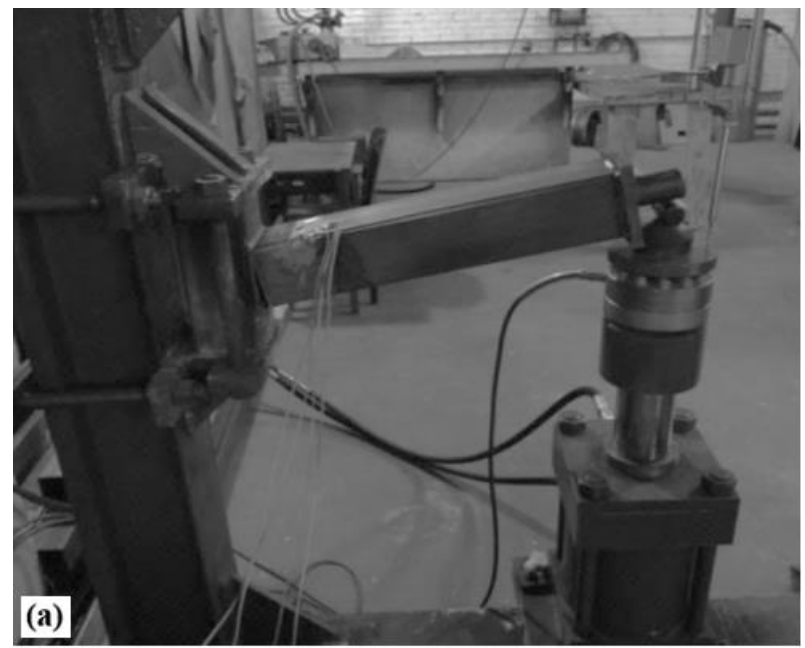




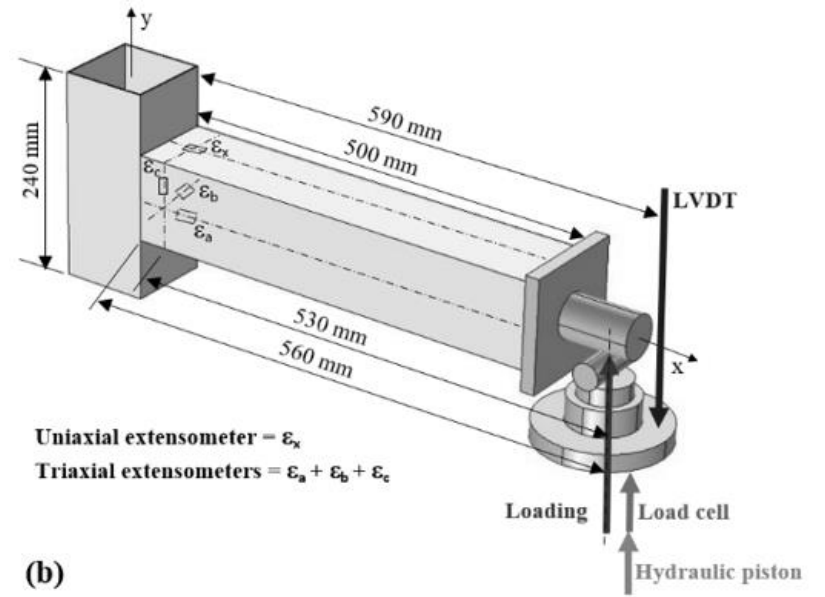

Fig. 5: (a) Assembly Mounted on Fixation Portico, Being Subjected to Simple Bending; (b) Schematic Drawing of the Simple Bending Test [5].

Thus, on the upper plan of the beam the specific strains are acquired $\left(\varepsilon_{\mathrm{x}}\right)$ through an uniaxial extensometer, and the normal stresses are calculated by Hooke's formula $\left(\sigma_{\mathrm{x}}=\mathrm{E} \cdot \varepsilon_{\mathrm{x}}\right)$. The stress/strain shear is obtained by the Equations 1 and 2, from the strains measured by the triaxial extensometers that are on the side plane of the beam, as presented in Fig. 5. Note that $\varepsilon_{\mathrm{a}}$ is in the longitudinal beam direction, or "X", and $\varepsilon_{\mathrm{c}}$ the $90^{\circ}$ or "Y", and the $\varepsilon_{\mathrm{b}} 45^{\circ}$ [15], [16].

$\tau_{1,2}=\left[\frac{\mathrm{E}}{2}\left(\frac{\varepsilon_{\mathrm{A}}+\varepsilon_{\mathrm{c}}}{1-\mathrm{v}}\right) \pm \frac{1}{1+\mathrm{v}} \sqrt{\left(\varepsilon_{\mathrm{A}}-\varepsilon_{\mathrm{c}}\right)^{2}+\left(2 \varepsilon_{\mathrm{B}}-\varepsilon_{\mathrm{A}}-\varepsilon_{\mathrm{c}}\right)^{2}}\right]$

$\varepsilon_{1,2}=\left(\frac{\varepsilon_{\mathrm{A}}+\varepsilon_{\mathrm{c}}}{2}\right) \pm \frac{1}{2} \sqrt{\left(\varepsilon_{\mathrm{A}}-\varepsilon_{\mathrm{c}}\right)^{2}+\left(2 \varepsilon_{\mathrm{B}}-\varepsilon_{\mathrm{A}}-\varepsilon_{\mathrm{c}}\right)^{2}}$

\section{Results and discussions}

\subsection{Microhardness and cooling rates $\left(\Delta t_{8 / 5}\right)$}

The transverse microhardness profile for the longitudinal weld bead with $0.3 \mathrm{~kJ} / \mathrm{mm}$ and $1.6 \mathrm{~kJ} / \mathrm{mm}$ is shown in Fig. 6, as function of distance from the weld bead centerline. Through this, it has been identified the base metal unchanged (BMU), the curved base metal (CBM, the corners of the tube), the weld metal (WM) and HAZ.

(a)

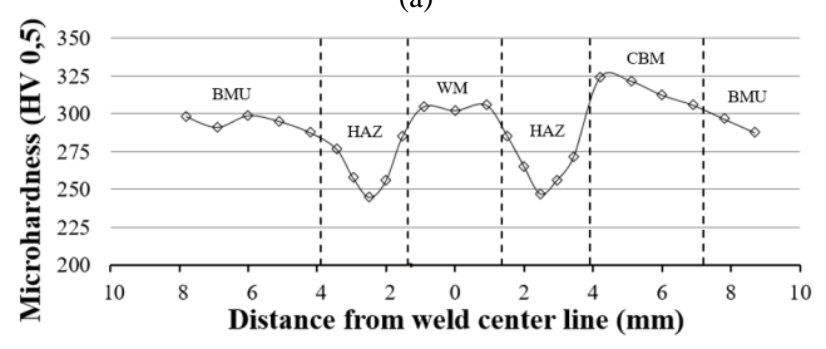

(b)

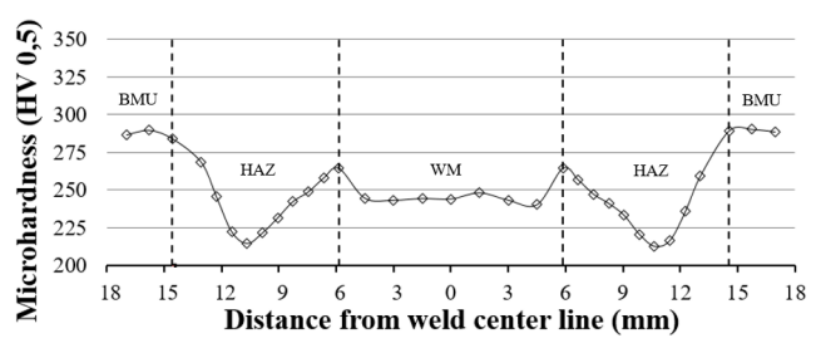

Fig. 6: Microhardness Profile for the Longitudinal Joint Weld Bead: (a) $0.3 \mathrm{~kJ} / \mathrm{mm}$; (b) $1.6 \mathrm{~kJ} / \mathrm{mm}$.

The HAZ identified by microhardness profile in Fig. 6 is the result of microstructural changes in BM associated with the thermal cycles during welding. Therefore, they have presented different microstructures from each other, beyond microhardness and mechanical properties different [17]. It is observed in Fig. 6 an accentuated decline in the hardness in HAZ and an increase in base metal on the corner or curve (CBM) when compared to the base metal in the non-formed region (BMU). Another evident fact is the existence of microhardness gradient in HAZ; that phenomenon is a consequence of the temperature gradient developed during welding [18].

The cooling time between $800{ }^{\circ} \mathrm{C}$ and $500{ }^{\circ} \mathrm{C}$ is often used in welding. The reason is that the cooling rate of the welded joint is very important to determine its microstructure and mechanical properties [2], [18], [19], especially in HAZ [20]. The local microstructure and the properties of any point along the weld bead are determined by the thermal cycle undergone at the point in question, with the peak temperature decreasing as distance from the weld bead center line increases [18], [21]. Fig. 7(a) presents the relationship between the heat input and weld metal cooling rate $\left(\Delta \mathrm{t}_{8 / 5}\right)$. Fig. 7 (b) lists the minimum microhardness WM and HAZ with weld metal cooling rate $\left(\Delta \mathrm{t}_{8 / 5}\right)$.
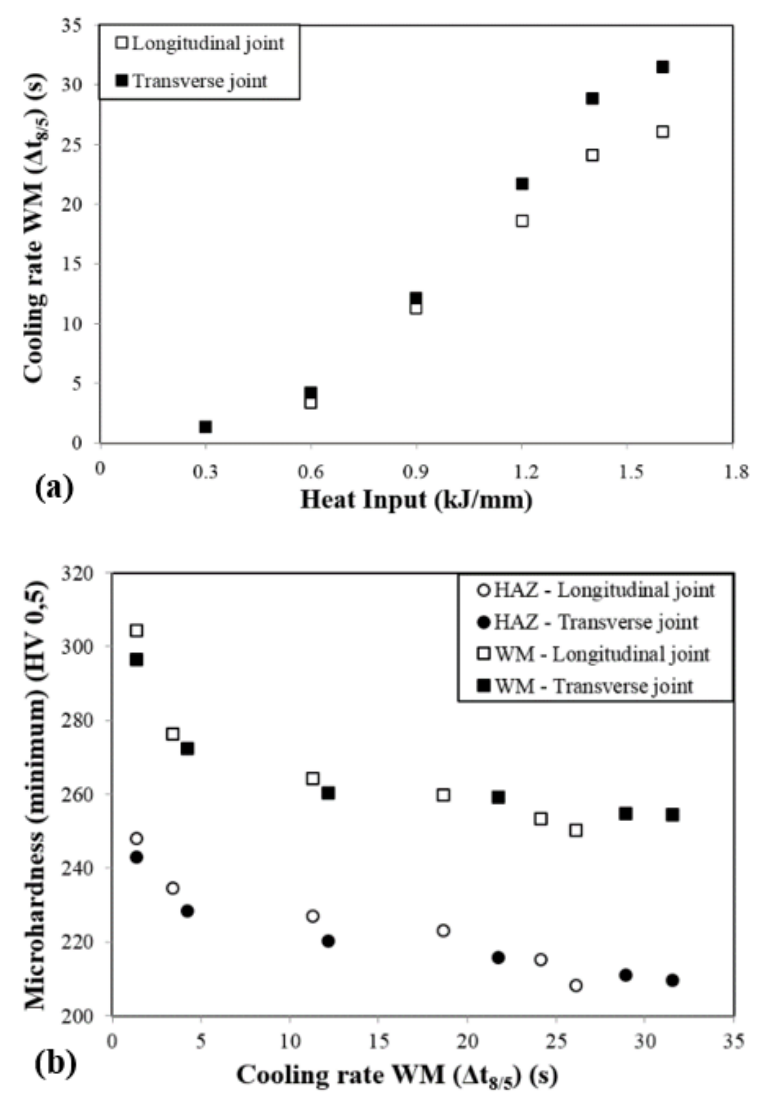

Fig. 7: (a) $\Delta t_{8 / 5} X$ Heat Input; (b) $\Delta t_{8 / 5} X$ Microhardness (Minimum) WM and HAZ.

The values $\Delta \mathrm{t}_{8 / 5}$ shown in Fig. 7(a) increased proportionally to the elevation in heat input, i.e., the higher the heat input, lower is the cooling rate WM. It can be observed in Fig. 7(b) that the higher 
the $\Delta \mathrm{t}_{8 / 5}$ in the weld metal, the lower the microhardness measure in the HAZ and WM. Therefore, probably the main factor for the microhardness reduction in the HAZ and WM was the heat input increase, as the results presented by [17], [20], [22], and [23].

\subsection{Geometry of joints}

The cross section area (WM and GCR of HAZ) of the longitudinal and transverse welded joints is shown in Fig. 8 as function of heat input. It is observed in these figures, the area of the WM and GCR of HAZ increases as the heat input raises, regardless the type welded joint. This explains why the heat input is inversely proportional to the welding speed. Consequently, with the reduction of the welding speed there is an increase in weld metal deposited per unit of time. However, the area the GCR of HAZ of the transverse welded joints with heat inputs higher than $0.6 \mathrm{~kJ} / \mathrm{mm}$ were superior to longitudinal welded joints. That happened because heat does not have enough area to be spreaded, since the plate thickness is 3 $\mathrm{mm}$, thus, the GCR of the longitudinal welded joints becomes restricted, but dominant.

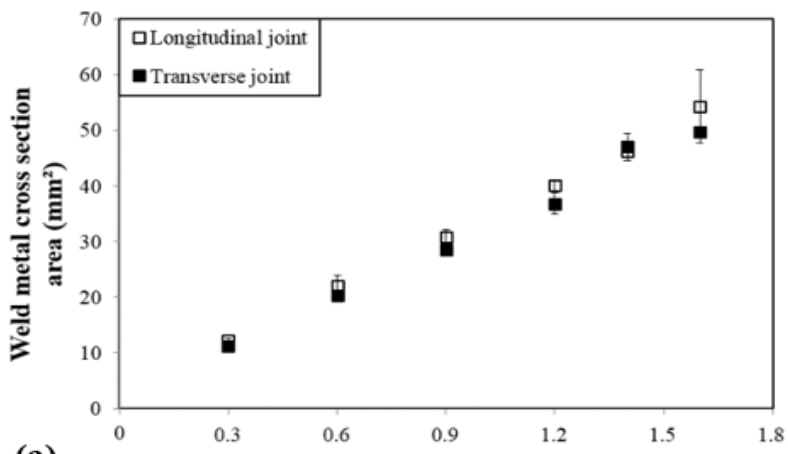

(a)

Heat input $(\mathrm{kJ} / \mathrm{mm})$

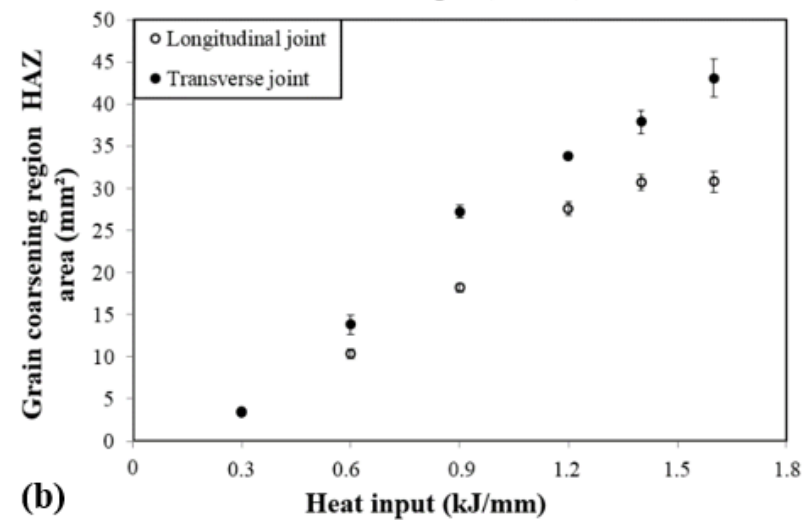

Fig. 8: (a) WM Cross Section Area X Heat Input; (b) Grain Coarsening Region (GCR) HAZ Area X Heat Input.

Fig. 9 shows the influence of heat input on the throat of the welds As indicated in this figure, the throat of the transverse welded joints had a considerable increase between 0.3 to $1.4 \mathrm{~kJ} / \mathrm{mm}$, as occurred (small) reduction with $1.6 \mathrm{~kJ} / \mathrm{mm}$. Only longitudinal welded joints with $0.3 \mathrm{~kJ} / \mathrm{mm}$ did not present complete penetration. All longitudinal welded joints with higher heat inputs were welded with complete penetration or excessive penetration; the throat was the same in all the cases and, therefore, they have identical resistance sections.

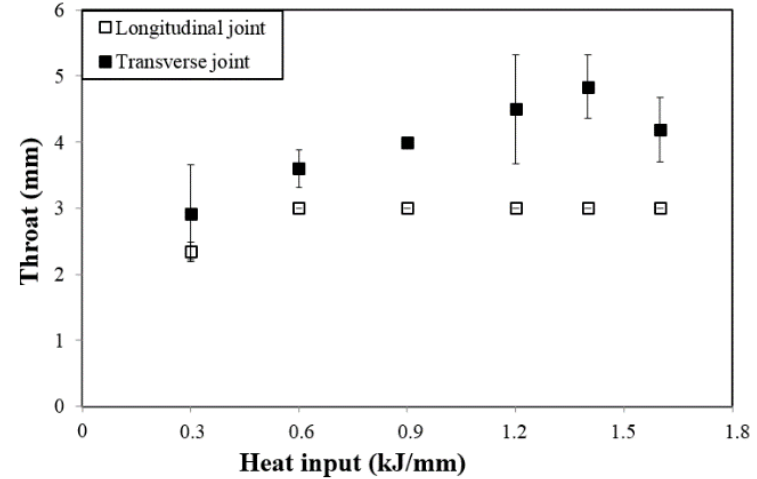

Fig. 9: Throat as a Function of Heat Input.

The measures presented in this subsection must be taken into account, precisely because they interfere directly with the bending strength of the welded joints. As can be observed, the WM area increase contributed to enlarge bending strength of welded joints, as long as the area of the resistance section keeps expanding. From a certain point on, the area of the resistant section does not increase with the further higher heat inputs. What happens is only a reduction of microhardness and an enlargement in the HAZ area. In function of these factors, the structural integrity of welded joints can be impaired when used very high heat input, as the "notch effect" promoted in the regions of lower microhardness is higher and the probability of failure in this region increases [5].

\subsection{Strength of welded joints to simple bending}

The data relating to the maximum force supported by the structures and the strains measured are presented in Table 4, as function of heat input. The main strains acquired by electrical resistance extensometers relate to the force applied and the normal and shear stresses of rectangular tubular profiles on their upper and left lateral plans for different heat inputs. The strain, force and stress values will be shown. They refer to the exact moment of the rupture, a fact easily verified through the force/strain records acquired during the test, by the sudden reduction of the force exerted on the load cell. The table below also presents the average areas of resistant section " $A_{S}$ " (from the considered welded joints), i.e., the addition of the length products of each side of the profile to the respective welded joint throat [12].

The results presented in Table 4 show that the longitudinal and transverse welded joints have progressively increased the ultimate rupture force, as the heat input is elevated up to $1.2 \mathrm{~kJ} / \mathrm{mm}$. With this heat input, the bending strengths of the longitudinal weld joints $(\mathrm{E} 4 / 120)$ and transverse $(\mathrm{E} 10 / 120)$ are $62.0 \%$ and $16.2 \%$ higher than those welded with $0.3 \mathrm{~kJ} / \mathrm{mm}$ (E1/120 and E7/120), respectively. It can also be seen in this table that: (a) heat inputs exceeding $1.2 \mathrm{~kJ} / \mathrm{mm}$ apparently are not effective to increase the bending strength of the joints in concern, from this heat input on, the observed force values are very close; (b) the longitudinal weld joints (E4/120) exhibited bending strength $23.8 \%$ higher than transverse welded joints (E10/120).

Table 4: Maximum Forces Supported by the Structures and Strain Measures, Resulting Shear Strain and Normal

\begin{tabular}{|c|c|c|c|c|c|c|c|}
\hline \multirow[b]{2}{*}{ Experiment } & \multirow[b]{2}{*}{$\begin{array}{l}\text { Average Heat } \\
\text { Input }(\mathrm{kJ} / \mathrm{mm})\end{array}$} & \multirow[b]{2}{*}{$\begin{array}{c}\text { Average Area of the } \\
\text { Section Resistance }\left(\mathrm{mm}^{2}\right)\end{array}$} & \multirow[b]{2}{*}{$\begin{array}{l}\text { Maximum Force Supported } \\
\text { by the Structure }(\mathrm{kN})\end{array}$} & \multicolumn{2}{|c|}{ Shear (max.) } & \multicolumn{2}{|c|}{$*$ Normal (max.) } \\
\hline & & & & $\begin{array}{l}\text { Stress } \\
(\mathrm{MPa})\end{array}$ & $\begin{array}{c}\text { Strain } \\
(\mathrm{mm} / \mathrm{mm})\end{array}$ & $\begin{array}{l}\text { Stress } \\
(\mathrm{MPa})\end{array}$ & $\begin{array}{c}\text { Strain } \\
(\mathrm{mm} / \mathrm{mm})\end{array}$ \\
\hline E1/120 & 0.3 & 471 & 34.5 & 224.6 & 0.00093 & -511.9 & -0.00243 \\
\hline E3/120 & 0.9 & 600 & 40.0 & 409.4 & 0.00184 & -1072.9 & -0.00511 \\
\hline $\mathrm{E} 4 / 120$ & 1.2 & 600 & 40.1 & 436.1 & 0.00195 & -1139.6 & -0.00542 \\
\hline $\mathrm{E} 5 / 120$ & 1.4 & 600 & 40.3 & 462.5 & 0.00211 & -1294.2 & -0.00616 \\
\hline $\mathrm{E} 6 / 120$ & 1,6 & 600 & 39.5 & 378.8 & 0.00173 & -922.1 & -0.00472 \\
\hline
\end{tabular}




\begin{tabular}{|c|c|c|c|c|c|c|c|}
\hline E7/120 & 0.3 & 584 & 20.0 & 51.0 & 0.00024 & -234.3 & -0.00111 \\
\hline $\mathrm{E} 8 / 120$ & 0.6 & 720 & 22.7 & 59.2 & 0.00020 & -330.9 & -0.00157 \\
\hline E9/120 & 0.9 & 799 & 29.4 & 67.5 & 0.00025 & -424.1 & -0.00202 \\
\hline E10/120 & 1.2 & 900 & 32.4 & 99.7 & 0.00044 & -676.7 & -0.00322 \\
\hline E11/120 & 1.4 & 968 & 32.4 & 85.7 & 0.00033 & -616.3 & -0.00293 \\
\hline E12/120 & 1.6 & 839 & 31.2 & 70.7 & 0.00033 & -541.8 & -0.00258 \\
\hline
\end{tabular}

* The normal stress/strain is negative due to the uniaxial extensometer to be subjected to compressive forces.

As consequence of welding, the designers and welding engineers should be aware to the possible mechanical strength drop of the welded joints. The American Institute of Steel Construction (AISC) [9] and American Welding Society (AWS) D1.1 [12], among other sources, can be followed for the design of weldments, being all of them based on simplifications [6]. Furthermore, it is not enough at all the weld and base metals meet the toughness levels and ductility required by various standards and codes, since these results do not adequately represent the actual situations in which the various welded structures undergo [4].

Moreover, through the elementary theory of strength of materials, it is possible to calculate the normal stress $(\sigma=$ M.c/I) and shear $[\tau=\mathrm{V} . \mathrm{Q} /(\mathrm{I} .2 \mathrm{t})]$ acting on beams, where "M" is the moment, "c" the distance from the neutral axis to considered position, "I" is the moment of inertia, "V" the shear force, "Q" static moment in relation to the neutral line the transverse beam section located above the position considered and " $\mathrm{t}$ " the wall thickness the tube in this section [15], [16]. Thus, through a simple analysis of the above equations, it seems that the moment is predominant and not the shear strain, although these equations do not take into account the heat input with which the welded joints were produced. Besides, analyzing the Table 4 it can be noticed that normal strains are much higher than the shear ones.

\section{Conclusions}

Within the experimental limits of the present work and according to the results obtained, the following conclusions can be drawn:

- The thermal cycling acquired by inserting thermocouples type "S" in the weld pool showed that the cooling time between 800 and $500{ }^{\circ} \mathrm{C}$ increased proportionally with the elevation of heat input, independently to the type of joint. This increased interval $\Delta \mathrm{t}_{8 / 5}$ helped to reduce the microhardness and enlarge the area of HAZ.

- Comparing welded joints with the same heat input, the longitudinal ones were more resistant than the transverse ones.

- The heat input is the predominant factor in the bending strength of welded structures in this investigation, but only while significantly increasing the area of the resistance section of the welded joint (throat product by weld length).

- The BM and WM microhardness were higher than those of HAZ. However, the use of relatively higher heat inputs do not benefit the bending strength of welded joints, because there is a reduction of microhardness and expansion the area of HAZ in this case.

\section{Acknowledgements}

To Capes (Brazil) for granting the master's scholarship to one of the authors (RLD); to SSAB, and especially to Eng. João Ricardo Boff Preichard for providing the DOMEX $700 \mathrm{MC}^{\mathrm{TM}}$ steel square tubular profiles.

\section{References}

[1] Rajan, T. V.; Sharma, C. P.; Sharma, A. Heat Treatment: Principles and Techniques. PHI Learning, 2011.408 p.

[2] SSAB Tunnplat. Sheet Steel Joining Handbook: Joining of High Strength Steels. Sweden: SSAB Tunnplat AB, 2004.

[3] European Committee for Standardization. EN 10149-2. Hot Rolled Flat Products Made of High Yield Strength Steels for Cold Forming - Part 2: Delivery Conditions for Thermomechanically Rolled Steels. Brussels: ECS, 1995.
[4] Machado, I. G. Falhas de Estruturas de Aço Soldadas Devido a Reduzida Ductilidade. Soldagem \& Inspeção, 18(4): 391-403, Out/Dez 2013. http://dx.doi.org/10.1590/S010492242013000400011.

[5] Dalcin, R. L.; Machado, I. G.; Gonzalez, A. R.; Mazzaferro, J. A. E. Efeitos da Energia de Soldagem e Consumível Sobre a Resistência à Flexão Simples de Juntas Soldadas em Perfis Tubulares de Aço TMCP. Soldagem \& Inspeção, 21(1): 92-102, Jan/Mar 2016. http://dx.doi.org/10.1590/0104-9224/SI2101.09.

[6] Machado, I. G. Dimensionamento de Juntas Soldadas de Filete: Uma Revisão Crítica. Soldagem \& Inspeção, 16(2): 189-201, Abr/Jun 2011. http://dx.doi.org/10.1590/S010492242011000200011.

[7] Associação Brasileira de Normas Técnicas. NBR 6892. Materiais Metálicos: Ensaio de Tração à Temperatura Ambiente. Rio de Janeiro: ABNT, 2002.

[8] Miller, D. K. Welding of Steel Bridges: Highway Structures Design Handbook. Cleveland: The Lincoln Electric Company, 1994. 88 p.

[9] American Institute of Steel Construction. Welded Connections - A Primer for Engineers. Chicago: AISC, 2006.

[10] Machado, I. G. Novos Paradigmas para Especificação de Juntas Soldadas. Soldagem \& Inspeção, 17(3): 278-288, Jul/Set 2012. http://dx.doi.org/10.1590/S0104-92242012000300012.

[11] ESAB. Catálogo de Consumíveis. Disponível em: <http://www.esab.com.br/>. Acesso em: 12 Jan. 2015.

[12] American Welding Society. AWS D1.1. Structural Welding Code Steel. Miami: AWS, 2006.

[13] American Society for Testing and Materials. ASTM E3-95. Standard Practice for Preparation of Metallographic Specimens. West Conshohocken: ASTM, 1995.

[14] American Society for Testing and Materials. ASTM Standard E384-11. Standard Test Method for Knoop and Vickers Hardness of Materials. West Conshohocken: ASTM, 2011.

[15] Gere, J. M; Goodno, B. J. Mechanics of Materials. 7. Ed. Canada: Cengage Learning, 2009. 1022 p.

[16] Beer, F. P.; Johnston Jr, R. Resistência dos Materiais. 3. Ed. São Paulo: Pearson Makron Books, 1995. 1255 p.

[17] Hochhauser, F.; Ernst, W.; Rauch, R.; Vallant, R.; Enzinger, N. Influence of the Soft Zone on the Strength of Welded Modern HSLA Steels. Welding in the World, 56(5-6): 77-85, 2012. http://dx.doi.org/10.1007/BF03321352.

[18] Machado, I.G. Condução do Calor na Soldagem: Fundamentos \& Aplicações. 1. Ed. Porto Alegre: Imprensa Livre Editora LTDA, 2000. 119 p.

[19] Easterling, K. Introduction to the Physical Metallurgy of Welding. 2. Ed. Oxford: Butterworth-Heinemann LTD, 1992. 270 p.

[20] Pirinen, M. The Effects of Welding Heat Input on the Usability of High Strength Steels in Welded Structures: 2013. 174 p. Thesis (Doctor) - Lappeenranta University of Technology, Finland.

[21] Kou S. Welding Metallurgy. 2. Ed. John Wiley \& Sons, 2003. 461

[22] Górka, J. Influence of the Maximum Temperature of the Thermal Cycle on the Properties and Structure of the HAZ of Steel S700MC. IOSR Journal of Engineering, 3(11): 22-28, Nov 2013. http://dx.doi.org/10.9790/3021-031142228.

[23] Rocha, I.C.L.; Machado, I.G.; Mazzaferro, C.C.P. Mechanical and Metallurgical Properties of DP 1000 Steel Square Butt Welded Joints with GMAW. International Journal of Engineering \& Technology, 4(1): 26-34, 2015. http://dx.doi.org/10.14419/ijet.v4i1.3928. 